\title{
Trends in the Development of Labour Rights in the Beginning of the XXI Century
}

\author{
Bikeev Askhat Ahatovich \\ Kazan (Volga region) Federal University, 18 Kremlevskaya str., Kazan city, \\ 420008, Russia

\section{Lushnikov Andrey Mikhailovich}

Yaroslavl State University named after P. G. Demidov, 14 Soviet str., Yaroslavl city, 150000, Russia

Email: amlu0909@yandex.ru

Doi:10.5901/mjss.2014.v5n24p463

\section{Abstract}

At the turn of XX and XXI centuries the development of labour rights in the West, and today, and in Russia turns over to a new qualitative level. The employment rights of the employee of the XX century are the rights established in the industrial and partly of the post-industrial society. XXI century began, as the age of informational society in which fundamental changes took place in employment too. This inevitably led to changes in labour legislation and the list of labour rights, the development of which is on another level. In this situation, in special importance is adapting to the changes that is taking place, the achievement of high quality level of compliance with them, and defining the future perspectives of development of those or other legal phenomena. Therefore, on the basis of the revealed regularities of the development of labour rights we have defined the main trends of their development.

Keywords: labour law, development trends of labour rights, the expansion of labour rights, international labour standards, labour mobility.

\section{Introduction}

The XXI century began as the century of the information society, and labour rights set forth in the XX century not fit into the framework of the new social organization of labour relations. For this reason, the special urgency is got definition of tendencies of development of the totality of labour rights in the human rights system.

A kind of Manifesto for the forthcoming changes has been the release of the compilation "Labour law in the postindustrial era" [1], which was prepared by materials of the scientific conference organized in November 1993, faculty of law, University of Amsterdam. Similar to the above mentioned was the collective study "The idea of labour law" [2], which was prepared on the basis of materials of the scientific conference held in the College of St. Katerina at Cambridge University in April 2010. Trends of development of science of labour law was dedicated to the scientific conference held in April 2013 on the basis of the Kiev national University named after Taras Shevchenko and the Institute of state and law of NAS of Ukraine [3].

Two general social regularities exerted decisive influence on the development of labour rights in the new Millennium:

1) the technical revolution, combined with accelerated social evolution, the result of the interaction of which was the formation of a post-industrial society;

2) the process of globalization.

In the context of these patterns of global development of social relations connected with employment, we have identified the main trends of labour rights in the beginning of XXI century.

\section{Trend 1. The Recognition of the International Significance of Labour Rights and the Widening of the Scope (Expansion) of Labour Law}

Labour rights belong to the second generation of human rights, including in social rights, where they occupy the central place. Already the 1948 Universal Declaration of Human Rights (article 23-25) recorded a fairly comprehensive list of labour rights (the right to work, to just and favourable conditions of work, equal payment for equal work, to form trade 
unions, to rest and others)[4]. The dominant position of labour law occupies in the system of social human rights, in particular the 1966 International Covenant on Economic, Social and Cultural rights (article 6 of 13) [5]. The 1961 European Social Charter (amended in 1996) establishes that the employee has 18 labour rights [6].

According to experts of the International labour organization (hereinafter referred as "ILO"), a global approach to universal "threshold rights" - set of minimum rights, which may count any person, regardless of his status as employed, which, figuratively speaking, can not be sold and bought [7]. But the specific content of labour rights (guarantee of employment, minimum wage and other labour standards) depend primarily on the economic situation of the state, which is obliged to ensure that a minimum set of labour rights to the maximum available for the economic level, but not lower than defined by the norms of international law, which emphasizes a civilizational significance of labour rights.

"Both history and contemporary politics strongly suggest that pressure to develop more effective means of international coordination to ensure respect for labour standards will increase as international economic integration deepens. Most notably, the United States and Canada obtained agreements on labour standards in tandem with new international trade agreements" [8].

Labour rights are at the intersection of natural rights (on the basis of the origin) and positive rights (in order of fixing). This versatility labour right allows you to distribute this institute for other spheres of application of the professional work, which is different from the traditional labour wage (labour professional athletes, labour, state and municipal employees; persons undergoing non-military service and others). So we can talk about further expansion of the scope of the (expansion) of the regulations of labour legislation with the purpose of social protection of the labour rights of these categories of workers. For example, analysing foreign legislation and practice of its application, I. Ya. Kiselev marks the advent of the institute of "persons like workers", "quasi-workers", which to some extent spread guarantees of labour rights [9].

It is in this direction and goes and further improvement of the Labour code of the Russian Federation (hereinafter referred as "LC RF") [10]. In particular, it appeared the head 49.1 dedicated to the work of remote workers, and 54.1 governing the work of professional athletes and coaches.

\section{Trend 2. The Offset Value Priorities in the Content of Labour Rights in the Sphere of Ensuring the Comprehensive Development of Personality}

Scholars have proposed greater emphasis on individual employment rights, which are grounded in social ideals such as citizenship, autonomy and decent work [11]. Labour law provisions are intended to complement and reinforce the protection of personal non-property rights and other nonmaterial values, implemented by the civil law, in relation to the peculiarities of labour relations. They must ensure the rights and freedoms during the period of employment and, thus, to establish the status of "social citizenship" [12].

Due to the fact that in conditions of development of highly sophisticated technologies and distribution of computer equipment market economy cannot do without mass intellectually creative activity, to the labour market come highly skilled workers. New forms of work organization pose new requirements to the employee's personality and his ability to labour modified function of the worker.

In this respect the special importance acquires the right of a worker for vocational training. In the ILO 2004 Recommendation \# 195 "on human resources development: education, training and lifelong learning" [13] it is noted that education, training and lifelong learning are fundamental and should be an integral part of social policy of the States. Today, therefore, in every developed country created and constantly improved model of the "lifetime" of the development of the creative potential of the national workforce.

Thus, the values of human rights are increasingly moved from the sphere of economic and physical safety of any person in the sphere of subjective well-being and quality of working life". Personal worker rights (the right to vocational training; the right to moral encouragement, evaluation of the work achieved; the right to privacy and protection of personal data, the right to obtain information about working conditions, the right to dignity in labour activity and protection against mobbing) will become increasingly important.

\section{Trend 3. The Provision of Labour Law Labour Mobility of Workers, Formation of a Special Type "Transnational" and "Supranational" Labour Relations}

The XXI century is the century of globalization, which could not be reflected on the labour mobility of workers, which more and more acquires an international issue. This trend has a positive character (for example, leads to the creation of almost worldwide market) and negative (many States are unable to find their place in the global division of labour reality that 
leads to a regression in the legal regulation of labour relations).

In this regard, the UN General Assembly at its 24th special session, held in Geneva in June 2000, adopted a special policy aimed at maintaining social stability in the world. In February 2002 under the auspices of the ILO was formed world Commission on the social consequences of globalization, which concluded its work in 2004 was emphasized special importance in the global economy, respect for workers' rights and legal norms on the basis of fairness, solidarity and gender equality [14]. Ensuring effective employment in conditions of globalization were sent to the ILO 2008 Declaration on social justice for a fair globalization [15] and the 2009 Global jobs Pact [16].

The globalization of the labour market has put on the agenda the question of external (international) labour migration. At the turn of the Millennium international migration has become universal, reflecting the development of the globalization tendencies in different spheres of life activity of the world community. Migration is another global problem, the solution of which in the future should occur, including, and means of employment law, from the standpoint of the protection of labour rights and freedoms of all persons, regardless of their citizenship and place of permanent residence.

"Multiple international legal regimes - in human rights law, refugee law, labour law, trade law and criminal law address, to some degree, the rights and privileges that should be accorded to aliens working within the territories of states parties.

Comprehending the effects of multiple legal regimes arising at domestic, regional, and international levels is of course a difficult business, and the challenge of doing so reacts differently with different jurisprudential sensibilities: whereas some see the gradual accretion of global constitutionalism or at least a welcome form of regulatory competition, others warn of the destructive effects of fragmentation" [17].

Globalization has another aspect that is associated with ever-expanding activities of transnational corporations (TNCS). The XXI century named a special level of legal regulation of labour relations will be further developed. I. Ya. Kiselev called these employment relationships as "transnational" or "supranational", which are governed by international and national labour laws and international collective agreements [18]. In the Russian legislation these problems still to be solved.

\section{Trend 4. Increased Flexibility (Differentiation and Individualization) in the Legal Regulation of Labour Relations in Combination with the Protection of Labour Rights}

The ability of modern labour law to acquire the necessary flexibility largely depends on its survival as a necessary and important for the social institute. Modern scientist A.M. Kurennoy reasonably believes that the problem of "flexibility at work should be recognized one of the national interests of the Russian Federation", the question that must be addressed both at the legislative and enforcement level [19].

At the turn of the century can be clearly traced the loss of industrial priority in attracting labour force. Replaced by a new type of production - flexible, innovative production and, consequently, new post-industrial types of work organization and management [20] and the emergence of non-standard forms of employment (for example, teleworkers; Agency work; part-time schedule; temporary employment).

Such atypical employment has its positive and negative consequences. The positive thing is that atypical employment allows to provide employment for those categories of citizens, for whom full-time employment for any reason, difficult or undesirable (older workers, single mothers, unemployed youth without professional skills and others). The negative consequences of the expansion of atypical employment are associated primarily with the absence or reduction of social protection guarantees of the labour rights of workers, with the lack of prospects for professional development, because the employer is not interested to invest in the improvement of professional qualifications. "Workers in these jobs are engaged on a casual or contract basis, few develop portable skills, experience or contacts (and so have no real career development) and often work unsociable hours" [21].

Therefore, the strengthening of flexibility (differentiation and individualization) in the legal regulation of the employment relationship must be combined with the protection of labour rights of the employee. You can talk about the urgent need by means of labour law to solve the problem of limits of flexibility in labour relations, to find a balance between flexibility of legal regulation of labour relations, on the one hand, and protection of employment rights of the employee, on the other.

\section{Trend 5. Harmonization of Individual and Collective Labour Rights, Based on the Extension of Social Partnership}

This trend is connected with expanding the scope of social dialogue (social partnership), an adaptation of collective 
labour relations to the economic realities of the XXI century.

The beginning of the XXI century was marked by significant changes in the social organization of labour reality. They are associated with the strengthening of individual (private) began in the legal regulation of labour relations and the reduced role of trade unions of workers of professional solidarity.

Meanwhile, experts of the ILO, based on generalization of modern foreign practice of labour relations, find many indications that the employers' associations and trade unions that are adapting to the modern realities of economic globalization and growing competition. They change their structure and methods, improve the mechanisms of social dialogue. In addition, practically on all continents of the state more actively than before, take part in solving social issues. All this testifies about the General trends in the development of a legal mechanism of social partnership, its adaptation to modern conditions.

As an increasing number of international associations of employees and the activation of their activity, including on the basis of the legislation of the European Union (European works councils), or on the basis of agreements between multinational enterprises and trade unions (global company councils). It is not only on the mutual exchange of information and consultation, but also about the cases of framework agreements between multinational enterprises and global Union federations.

\section{Trend 6. The Priority of International Standards of Labour Rights}

Considering the tendency of the priority of international standards on labour rights connected with the increase of the role of generally recognized principles and norms of international labour law in conditions of globalization. It is possible to note the strengthening of the authority of international labour standards, many of which act as internal national law and even has the priority in comparison with him. Formed by the mechanism of direct provision of international legal protection of labour rights of individual workers and showing signs of becoming regional labour standards in supranational law, for example, in the countries of the European Union. In these conditions the value and the previous notions of unlimited sovereignty of the nation-state in the regulation of labour relations has been lost.

We emphasize that certain changes in Russian legislation, were the direct consequence of the ratification of international agreements, first of all ILO conventions. So, in 2010 our country ratificated Convention \# 187 on promotional framework for occupational safety and health at work 2006 [22] of ILO, that has led to the fact that the Federal law dated on July 18, 2011 \# 238-FZ [23] added in the LC of the RF part 14 to the art. 209, where it was first defined the concept of professional risk. Part 15 of art. 209 of the LC of the Russian Federation for the first time defined the management of professional risks.

The most complete expression of the international standards of labour rights received in the ILO conventions and recommendations. The modern stage in the development of ILO standards-related activities is inextricably linked with the adoption of the 1998 Declaration on fundamental principles and rights at work and its follow-up [24], and the concept of decent work, which is to ensure that women and men had the opportunity to obtain decent and productive work in conditions of freedom, equity, security and human dignity [25].

Thus, the strategy for the development of labour relations in the XXI century should be based on enabling equal access of all citizens to the fundamental rights and freedoms - the right to work and social security, freedom of association, equality of opportunities of each, non-discrimination and non-forced work.

\section{Conclusion}

Thus, the main trends in the development of labour law can be revealed today, not at the level of divination or arbitrary projections, but based on the seeds of the future today.

These trends do not deny the continuity with centuries-old process of formation and development of labour law. Moreover, they reflect general and industry-specific patterns of development law. These trends will certainly have an impact on all institutions of general and special parts of labour law. Leading systematizing factors in industry are its object and method. Accordingly, the first three trends and partly fourth connected with formation of the subject of labour law in the post-industrial era. Following from these trends affect the change in the method of legal regulation of labour relations in the XXI century.

\section{References}

Labour Law in the Post-industrial Era. Aldershot, 1994. Pp. 105, 133, etc. 
The idea of Labour Law. Oxford, 2011. 454 p.

Trends in the development of science of labour law and law of social welfare. Kiyev, 2013. 676 p.

The Universal Declaration of Human Rights of 1948. Date Views 18.06.2014 www.un.org/en/documents/udhr/.

International Covenant on Economic, Social and Cultural rights of 1966. Date Views 18.06.2014 www.ohchr.org/EN/Professional Interest/Pages/CESCR.aspx.

European Social Charter of 1961. Date Views 18.06.2014 www.conventions.coe.int/Treaty/en/Treaties/Html/035.htm.

Boivin, I., Odero A. Committee of experts on application of conventions and recommendations: achievements in improvement of the national labor legislation // International Labour Review, vol. 144 \# 4, vol. 145 \#1-2, 2008. P. 117-132.

Banks, K.. Trade, Labour and International Governance: An Inquiry into the Potential Effectiveness of the New International Labour Law // Berkeley Journal of Employment and Labour Law, \# 32 (1), 2011. P. 48.

Kiselev I.Ya. New shape of the labor law of the West countries (break in post-industrial society). Moscow, 2003. P. 17-21.

Russian newspaper. 2001. December 31.

Frazer, A. Reconceiving Labour Law: The Labour Market Regulation Project // Macquarie Law Journal, \#8, 2008. P. 22.

Kiselev I.Ya. New shape of the labor law of the West countries (break in post-industrial society). Moscow, 2003. P. 44.

ILO Recommendation \# 195 concerning Human Resources Development: Education, Training and Lifelong Learning. Date Views 20.06.2014 www.conventions.ru/view_base.php?id=626

Fair globalization: creation of opportunities for all. Report of the World commission on social aspects of globalization. Geneva, 2004.

ILO Declaration on Social Justice for a Fair Globalization. Date Views 20.06.2014 www.un.org/ru/documents/decl_conv/declarations/ pdf/fair_globalization.pdf

Recovery from the crisis: The global pact on workplaces. Date Views 20.06.2014 www.ilo.org/public/russian/region/eurpro/moscow/ news/2009/ilc98cpi_r3_200906_ru.pdf.

Thomas, Ch. Convergences and Divergences in International Legal Norms on Migrant Labour // Comparative Labour Law\&Policy Journal, \# 32, 2011. P. 405, 406.

Kiselev I.Ya.. Destinies of the labor law in the XXI century // Labor law issues, \# 5, 2006. P. 13.

Kurennoy A.M. Flexibility in the work sphere: modern Russian realities. Modern trends in the development of labour law and law of social welfare. Moscow, 2007. P. 327.

Kiselev I.Ya., 2003. Current trends of legal regulation of non-standard forms of employment in the West countries // Labour abroad, \# 1 , 2003. P. 113-137.

Frazer, A. Reconceiving Labour Law: The Labour Market Regulation Project // Macquarie Law Journal, \# 8, 2008. P. 21-22.

Convention № 187 on promotional framework for occupational safety and health at work of 2006. Date Views 18.06.2014 www.ilo.org/dyn/normlex/en/f?p=NORMLEXPUB:12100:0::NO::P12100_INSTRUMENT_ID:312332.

Russian newspaper. 2011. July 22.

ILO Declaration on Fundamental Principles and Rights at Work of 1998. Date Views 18.06.2014 www.ilo.org/dyn/normlex/en/f?p= 1000:62:0::NO:62:P62_LIST_ENTRIE_ID:2453911:NO.

Overcoming of global crisis in the relation of workplaces. Report of the Director General. International Labour conference 98th session, 2009. International Labour Office, Geneva. Date Views 20.06.2014 www.sartraccc.ru/Traffic/scien_rep/0025/wcms.pdf 